\title{
Incidence and duration of increased somatic cell count in Swedish dairy cows and associations with milking system type
}

\author{
J. Frössling, ${ }^{*} \dagger^{1}$ A. Ohlson, $\ddagger$ and C. Hallén-Sandgren§ \\ *Department of Animal Environment and Health, Swedish University of Agricultural Sciences (SLU), PO Box 234, SE-53223 Skara, Sweden \\ †Department of Disease Control and Epidemiology, National Veterinary Institute (SVA), SE-75189 Uppsala, Sweden \\ ‡Department of Animal Health, Växa Sverige, PO Box 30204, SE-10425 Stockholm, Sweden \\ §Department of Dairy Advice, DeLaval International AB, PO Box 39, SE-14721 Tumba, Sweden
}

\begin{abstract}
Mastitis is one of the most costly diseases in dairy cows worldwide. Increased somatic cell count (SCC) is an indication of mastitis, often subclinical, which implies bacterial infection without clinical signs of inflammation. The aim was to investigate the occurrence of elevated udder SCC (defined as $\geq 200,000$ cells $/ \mathrm{mL}$ ) over the lactation period, and before and after the dry period, for cows of different parity. The aim was also to analyze the association between prevalence and incidence of increased udder SCC and information on cow and herd level, such as breed and milking system type. Data were extracted from the Swedish Official Milk Recording Scheme between January 1, 2008, and December 31, 2011, including all herds with a yearly average of $>60$ cows. The data include descriptive information on herd and cow level and the results from the systematic test milking. The data included the following: for 2009, 239,182 cows in 1,633 herds; for 2010, 251,852 cows in 1,680 herds; and for 2011, 247,746 cows in 1,596 herds. The results show a peak in elevated udder SCC during the late summer season and that the highest proportion of cases occurs during the first lactation month; the latter was most prominent for primiparous cows. Forty-seven percent of all cows with elevated SCC recovered during dry period (went from high to low SCC), whereas $34 \%$ of all cows with low SCC before the dry period had an elevated SCC at first testing after calving. For first lactation cows, $19 \%$ had an elevated SCC at first test milking. When the outcomes for the 3 consecutive years were reanalyzed, it was confirmed that the effect of fixed factors such as breed, milk yield, and parity did not change over time, whereas the effect of milking system type did. For the incidence of becoming a new case and the prevalence of cows with elevated udder SCC, automatic milking sys-
\end{abstract}

Received November 19, 2016

Accepted May 3, 2017.

${ }^{1}$ Corresponding author: jenny.frossling@sva.se tem (AMS) was associated with reduced SCC in 2009 but associated with increased SCC in 2011. Regarding the proportion of new cases of elevated SCC per cow and year, AMS appeared to be a risk factor for all 3 yr, but the effect decreased over time. The shift for AMS from protective to risk factor regarding incidence of new cases and number of recordings with elevated SCC might reflect a change of the AMS population over these years. The findings indicate the need for appropriate udder health management customized to the system.

Key words: mastitis, seasonal variation, risk factor, milking system type

\section{INTRODUCTION}

Mastitis is one of the most costly diseases in dairy cows worldwide. Although the yearly incidence of veterinary treated mastitis in Sweden has decreased during the last $10 \mathrm{yr}$, from $16 \%$ in 2004 to $11 \%$ in 2014 (Växa Sverige, 2015), mastitis is still the most common disease among Swedish dairy cows. In a healthy cow the composite SCC from all 4 quarters usually is $<100,000$ cells $/ \mathrm{mL}$ in milk, and this is influenced by age, breed, lactation stage, and milk yield (Nyman et al., 2014). Increased SCC $(>200,000$ cells $/ \mathrm{mL})$ is an indication of mastitis, often subclinical, which implies bacterial infection without clinical signs of inflammation (Dohoo and Leslie, 1991). Subclinical mastitis can cause substantial economic loss due to reduced milk production (Nyman et al., 2014) and reduced payment because of high bulk milk SCC. Moreover, cows with subclinical mastitis should be considered a risk for spread of mastitis pathogens within and between herds. The most common bacteria isolated from milk samples from cows with elevated SCC in Sweden are Staphylococcus aureus (31\%), CNS (27\%), Streptococcus dysgalactiae (15\%), Streptococcus uberis (14\%), Escherichia coli (4.8\%), and Streptococcus spp. (3.1\%; Persson et al., 2011).

The development of dairy herds in recent decades has been toward fewer but larger herds. Between 1980 and 
2008, the number of herds decreased by $85 \%$ (Swedish Board of Agriculture, 2010) and the number of dairy cows decreased by $46 \%$. During the same time period, the average herd size increased from 15 to 55 cows. The automatic milking system (AMS) was introduced for the first time in 1998, and in the last decade the implementation of AMS has progressed rapidly. In 2014, AMS herds produced approximately $25 \%$ of the total milk volume in Sweden. Several studies have shown that the bulk milk SCC increases during the transition to AMS and reports from Denmark, Finland, and Sweden have indicated that AMS herds have higher bulk milk SCC compared with herds with a conventional milking system, and also higher SCC at individual cow level (Rasmussen et al., 2002; Persson Waller et al., 2003; Hovinen et al., 2009).

Several studies have identified individual risk factors for mastitis in AMS herds (Persson Waller et al., 2003; Bach et al., 2007; Hovinen et al., 2009; Dohmen et al., 2010). However, most have been limited to a certain part of lactation or first-parity cows. To update and improve the scientific knowledge about occurrence of clinical and subclinical mastitis in the modern dairy cow, analyses of incidence and duration of elevated SCC in individual cows in AMS herds and conventional herds, respectively, in relation to season, parity, and lactation stage, are needed.

The aim of this paper was to investigate the occurrence of elevated udder SCC, over the whole lactation cycle, including the dry period, for cows of different parities. The aim was also to investigate seasonal variations in SCC and to analyze the association between prevalence or incidence of increased SCC and presumable predictive factors on cow level and herd level. In particular, the influence of milking system type and changes in production system was of interest.

\section{MATERIALS AND METHODS}

\section{Summary of Methodological Approach}

In this observational study, the occurrence of elevated udder SCC (i.e., $\geq 200,000$ cells $/ \mathrm{mL}$ ) was investigated by calculating the prevalence, incidence, and duration of elevated udder SCC in individual cows. In addition, the associations between potential risk factors and occurrence of elevated SCC were analyzed by investigating 3 different outcome measures using different multivariable regression models. Initial analysis indicated that the effect of different factors might vary over time, and because of this, each outcome was investigated in 3 different models set up separately for each year: 2009, 2010 , and 2011.

\section{Study Population and Collection of Data}

In the Swedish Official Milk Recording Scheme (Olsson et al., 2001), descriptive database information on herd and cow level and results from monthly milk recording are available. Data were extracted between January 1, 2008, and December 31, 2011, including all cows in herds with a yearly average of $>60$ cows. In 2009 , approximately $85 \%$ of the Swedish dairy cows were enrolled in the Swedish Official Milk Recording Scheme. Systematic test milking is carried out on a monthly basis, including several measurements such as milk yield, milk composition, and SCC. In 2009, there were roughly 360,000 dairy cows in Sweden, organized into 6,020 herds with an average herd size of 59 cows and an average milk yield of 9,162 $\mathrm{kg}$ of ECM per cow and year (Swedish Board of Agriculture, 2010). The 2 main breeds in Sweden are the Swedish Red (SRB) and the Swedish Holstein (SH), which at that time constituted 44 and $50 \%$ of the dairy cow population, respectively. The average Swedish cow in 2009 calved for the first time at 28 mo of age and the mean life span was 2.5 lactations (Swedish Dairy Association, 2010). On average, $37 \%$ of the cows in a herd were first-parity cows. A description of the study population is shown in Tables 1 and 2. The number of retrieved SCC records for this study was $8,846,787$. After data cleaning, including removal of duplicates and records where information of interest was missing, the number of SCC records used for further data management and analyses was 7,026,309.

\section{Occurrence of High SCC}

The prevalence of elevated udder SCC was estimated based on the proportion of cows with elevated SCC (cases) among all cows (cases and noncases) at a certain point in time. Incidence was estimated based on the number of new cases of elevated SCC divided by the number of cows at risk.

The udder SCC status at the previous, the present, and the next milk recording was assessed for each cow and month. The previous status was set to unknown if a previous recording was missing or occurred $>60 \mathrm{~d}$ before the present. Similarly, the status at the subsequent recording was set to unknown if the next recording was missing or occurred $>60$ d later. A cow was considered a new case if she had elevated SCC in the present month and at least 2 previous consecutively recordings with low SCC, or if the cow was a first-parity cow and the recording was the first within $60 \mathrm{~d}$ after calving. A cow that had a low SCC or was a heifer in the previous recording was considered at risk of becoming a case. If 
Table 1. The distribution of cows (\%) by categories of explanatory variables and for each year under study: 2009, 2010, and 2011

\begin{tabular}{lrrr}
\hline Item $^{1}$ & 2009 & 2010 & 2011 \\
\hline Milking system type & & & \\
Conventional & 89.2 & 68.9 & 65.0 \\
AMS & 1.5 & 13.5 & 31.5 \\
$\quad$ Transition & 9.4 & 17.6 & 3.5 \\
Parity & & & \\
1 & 44.1 & 44.4 & 43.9 \\
2 & 25.0 & 24.8 & 25.3 \\
$\geq 3$ & 30.9 & 30.9 & 30.9 \\
Breed & & & \\
SRB & 35.3 & 34.4 & 33.5 \\
SH & 49.5 & 49.8 & 49.9 \\
Mixed/other & 15.2 & 15.9 & 16.6 \\
Stall type & & & \\
Tie & 56.4 & 40.0 & 24.9 \\
Free $>6$ mo & 34.3 & 43.0 & 49.3 \\
Free $<6$ mo & 9.3 & 17.0 & 25.8 \\
Region & & & \\
1 & 12.1 & 12.1 & 12.1 \\
2 & 17.7 & 17.7 & 17.8 \\
3 & 12.5 & 12.5 & 12.8 \\
4 & 32.8 & 32.8 & 32.5 \\
5 & 24.9 & 24.9 & 24.8 \\
\hline
\end{tabular}

${ }^{1} \mathrm{AMS}=$ automatic milking system; $\mathrm{SRB}=$ Swedish Red; $\mathrm{SH}=$ Swedish Holstein.

a cow had one test with low SCC in a series of recordings with elevated SCC, this was disregarded and the cow was considered a case also at that recording. This was based on examination of data and our assessment that sporadic shifts across the SCC threshold of 200,000 cells/mL can be expected in some cows with clinical mastitis and that such observations were more likely to reflect persistent subclinical mastitis, rather than a truly healed, and then re-infected, udder. The number of disregarded observations were 189,202. In accordance with this, a cow was considered recovered and again at risk of becoming a case if she had low SCC, not only in the present, but also in the next recording. For each individual cow, SCC status before and after the dry

Table 2. The distribution of cows by continuous explanatory variables (average herd size over the year and herd average milk yield) for each year under study: 2009, 2010, and 2011

\begin{tabular}{lrrr}
\hline Item & 2009 & 2010 & 2011 \\
\hline Average herd size & & \\
$\quad$ 5th percentile & & & \\
25th percentile & 85 & 65 & 65 \\
Median & 119 & 122 & 85 \\
$\quad$ 75th percentile & 172 & 182 & 192 \\
95th percentile & 348 & 386 & 432 \\
Herd average daily milk yield, $\mathrm{kg}$ & & & \\
5th percentile & 24.2 & 24.1 & 23.8 \\
25th percentile & 27.3 & 27.1 & 27.3 \\
Median & 29.5 & 29.2 & 29.3 \\
75th percentile & 31.4 & 31.4 & 31.4 \\
5th percentile & 34.4 & 34.7 & 34.8 \\
\hline
\end{tabular}

${ }^{1}$ Number of cows. period was also compared. Information about dry cow treatment of individual cows was not available to us; however, the proportion of Swedish cows receiving such treatment has been estimated to be approximately $30 \%$ (National Veterinary Institute, 2012).

Incidence and prevalence was calculated by calendar month and lactation month and stratified by parity, to describe possible temporal trends.

\section{Regression Models}

Outcome Variables. The unit of interest in this study was cow, whereas the original units of observation were results from the monthly milk recording where all outcomes were related to the SCC status of each cow (determined as described above). These data were collapsed so that the total number of milk recordings, number of recordings where the cow had elevated SCC, number of recordings where the cow could be considered a new case, and number of recordings where the cow was at risk of becoming a new case of elevated SCC were summarized for each cow and year. The structure of the data is illustrated in the hypothetical data sets provided in the Supplemental Material (https://doi. org/10.3168/jds.2016-12333).

The first outcome was becoming a new case of elevated SCC at least once during the year (yes/no; $1 / 0$ ), hereafter referred to as new case incidence, and this was modeled using logistic regression. Only cows with at least 1 milk testing (mo) at risk was included in this part of analysis. The second outcome dealt with cows that were considered new cases of elevated SCC at least once during the year and was defined as the total number of times a cow became a new case of elevated SCC, hereafter referred to as new case count, and this was modeled using Poisson regression. The exposure variable (offset) was number of milk recordings where the cow was at risk of becoming a case. Initially, negative binomial regression was applied to model the new case incidence and the new case count outcomes simultaneously; however, these calculations did not converge. In the third model, all cows were included and the outcome was the number of milk recordings where the cow had elevated SCC, hereafter referred to as case prevalence. This was modeled by Poisson regression where the exposure variable was the total number of milk recordings during the same year. To adjust for clustering of observations (i.e., cows within herds), a 2-level modeling approach was used with herd included as a random variable in all models.

Explanatory Variables. The main potential predictor of interest was milking system type, defined as AMS, conventional, and in transition $(<6$ mo since installing AMS). Other explanatory variables on herd 
level were herd size (number of cows), average milk yield, stall type, and region (Tables 1 and 2). Herd size and average milk yield were continuous variables, where milk yield was expressed as the herd's mean milk yield in kilograms per cow-day. Stall type was defined as tie stall, free stall $>6$ mo, and free stall $<6$ mo. The stall type for all herds with AMS was free stall. Region was categorized into 5 geographical areas based on breeding and livestock associations (Swedish name given within parentheses): south (Skånesemin) $=1$, east (Hansa Husdjur) $=2$, west (Hallands Husdjur and Södra Älvsborgs Husdjur) $=3$, central (Freja Husdjur) $=4$, and north (Svea Husdjur and Norrmejerier) $=5$. Variables on cow level were breed and parity. Breed was classified into 3 categories: SRB, SH, and other breeds including mixed breeds. Parity was categorized into 1st, 2 nd, and $\geq 3$ rd lactation. In the new case incidence model, each cow's total number of recordings at risk of becoming a new case was also included.

Three different sets of estimates were computed for each outcome based on year (i.e., 2009, 2010, and 2011). Variables with $P<0.25$ in univariable regression were selected for inclusion in the model. For the multivariable regression, a backward stepwise approach was applied to eliminate variables at $P>0.05$. The presence of confounding was assessed by examining the effect of each explanatory variable on the coefficient of other variables in the model by adding the variable and removing it from the model and examining the change in the coefficients of the remaining model variables. If there was a change of $25 \%$ or more, the explanatory variable was included in the final model regardless of significance level. In addition, variables that were significantly associated with the outcome for 1 of the $3 \mathrm{yr}$ were included in all models of that outcome. The Akaike information criterion and Bayesian information criterion of different versions of models were also compared. Only main effects were tested. The linear association between continuous variables and the outcome was assessed and such variables were included either as continuous, as a set of continuous variables based on linear splines, or in categorized form based on percentiles, depending on which form had the best fit. Data management and statistical analyses were performed using Stata (Stata Statistical Software, release 13; StataCorp, College Station, TX). Model code for each model is given in the Supplemental Material (https://doi.org/10.3168/ jds.2016-12333).

\section{RESULTS}

The data included the following: for 2009, 239,182 cows in 1,633 herds; for 2010, 251,852 cows in 1,680 herds; and for 2011, 247,746 cows in 1,596 herds. Out of all cows, 61, 60, and $60 \%$ for 2009, 2010, and 2011, respectively, had elevated udder SCC at least once during the year. Approximately 20\% of these were cows with no previous history of elevated SCC. The majority of case cows had $1(78 \%)$ or $2(19 \%)$ episodes of elevated SCC within the same lactation. These episodes had a median duration of 2 test milkings (interquartile range 1-4). For the cows that had elevated SCC for the first time, the median duration was 1 test milking (interquartile range 1-3). The episodes of elevated SCC ended in different ways. Most cows recovered within the same lactation $(53 \%)$, some went into a dry period and then recovered (10\%), whereas some went into a dry period but continued to have elevated SCC in the next lactation $(18 \%)$, and some cows left the herd $(18 \%$ slaughtered, $1 \%$ euthanized).

The prevalence of cases (i.e., cows with a SCC $>200,000$ cells $/ \mathrm{mL}$ ) distributed over calendar months and lactation months are shown in Figures 1 and 2, respectively. We observed a peak of cases of elevated SCC in August for all $3 \mathrm{yr}$ under study [i.e., the later part of the pasture season (Figure 1)]. The highest proportion of cases of elevated SCC occurred during the first month after calving, and this pattern was most apparent in first lactating cows (Figure 2). The SCC status before and after the dry period (ending in 2008-2011) of individual cows is presented in Table 3 . Forty-three percent of all cows with elevated SCC seemed to recover during the dry period (i.e., they went from having elevated SCC to a low SCC), whereas $22 \%$ of all multiparous cows with low SCC before the dry period had elevated SCC after calving. Among primiparous cows, 19\% had elevated SCC at their first test milking.

Over the years, the proportion of cows in AMS system increased from $1.5 \%$ in 2009 to $31.5 \%$ in 2011 and also the proportion of cows in free stall, or in transition to free stall barns, increased over time. The distributions regarding parity, breed, and region remained stable during the study period. A description of the categorical variables for the tree years under study is presented in Table 1.

The number of observations and estimates from regression models of the 3 outcomes are shown in Tables 4,5 , and 6 , respectively. For the first outcome, new case incidence, AMS appeared to be a protective factor in 2009 and 2010 but a risk factor in 2011 (odds ratio of $0.47,0.84$, and $1.24 ; P<0.001$ all $3 \mathrm{yr}$ ). For the second outcome, new case count, AMS was a risk factor for all $3 \mathrm{yr}$ although the incidence risk ratio decreased over the $3 \mathrm{yr}$ under study (incidence risk ratio of 1.90, 1.20, and 1.07; $P<0.001$ all $3 \mathrm{yr}$ ). For the third outcome, case prevalence, AMS was a protective factor in 2009, not significant in 2010, and a risk factor in 2011 (preva- 


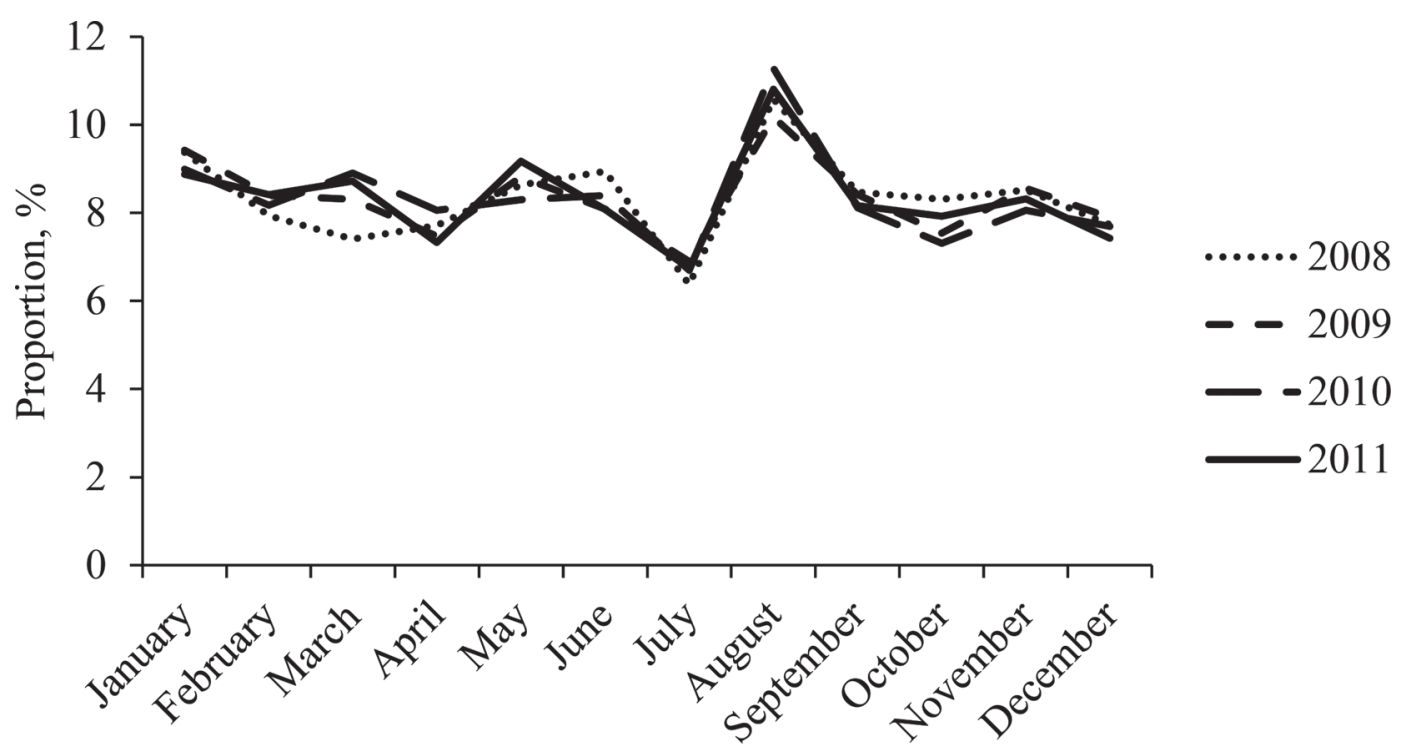

Calendar month

Figure 1. The proportion of cows with elevated SCC (>200,000/mL) distributed over calendar months for 2008, 2009, 2010, and 2011 (cows in herds with $>60$ cows, Sweden).

lence risk ratio of $0.85,1.01$, and $1.14 ; P<0.001,0.576$, and $<0.001$, respectively).

\section{DISCUSSION}

This observational study provides an overview on the occurrence of elevated udder SCC among Swedish dairy cows in herds with $>60$ cows. Our results show that the occurrence of elevated SCC varies according to season, parity, month in lactation, and milking system type. The uniqueness of the study is that it is based on information from a very large number of cows and herds, and that it includes cows (e.g., in different parities, and in different types of herds). One of the novel findings

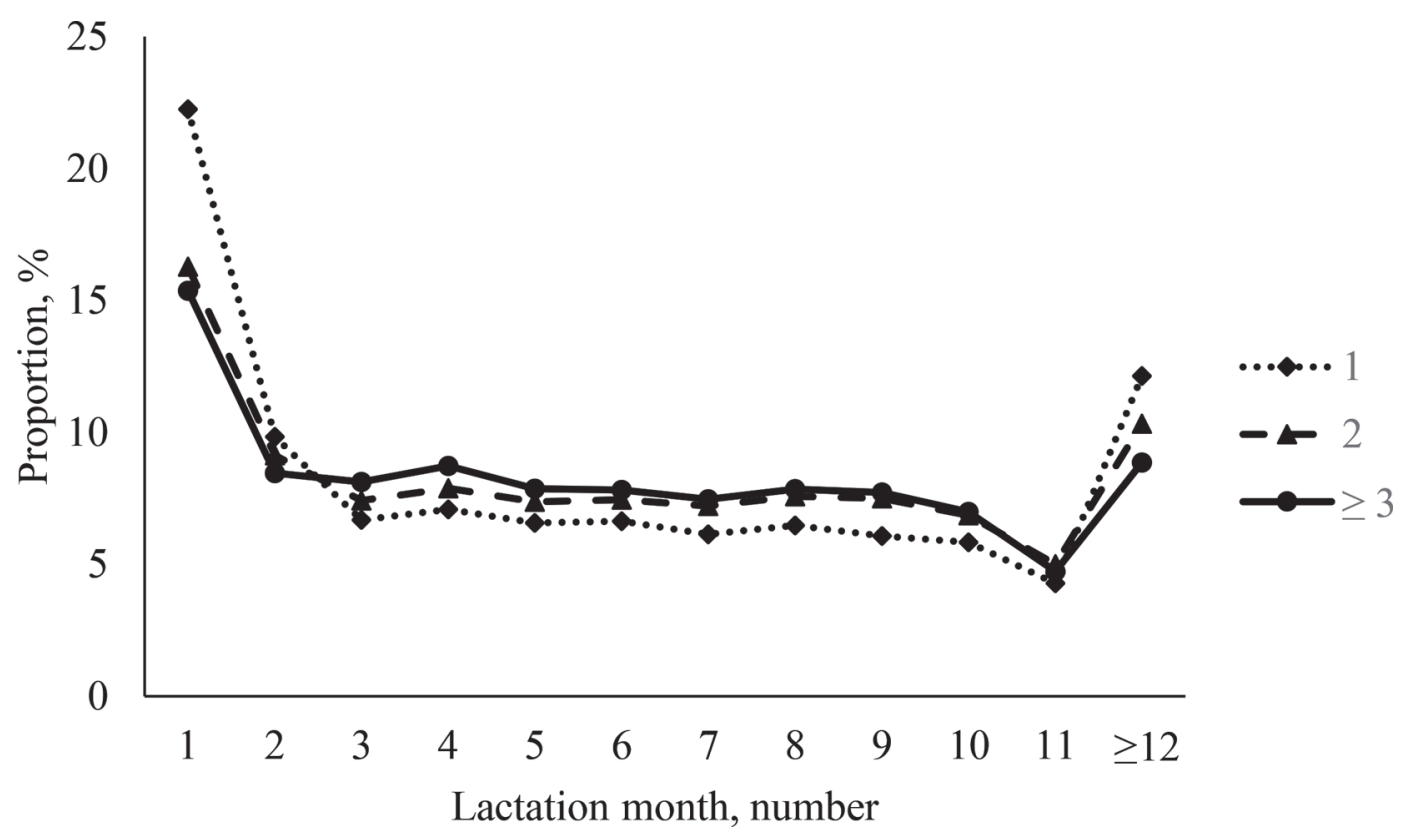

Figure 2. The proportion of cows over parity 1,2 , and $\geq 3$ with elevated SCC $(\geq 200,000 / \mathrm{mL})$ distributed over lactation months (cows in herds with $>60$ cows, Sweden, 2008-2011). 
Table 3. Udder SCC (cells/mL) before and after the dry period expressed as the number of cows by parity $(1,2 \text {, and } \geq 3)^{1}$

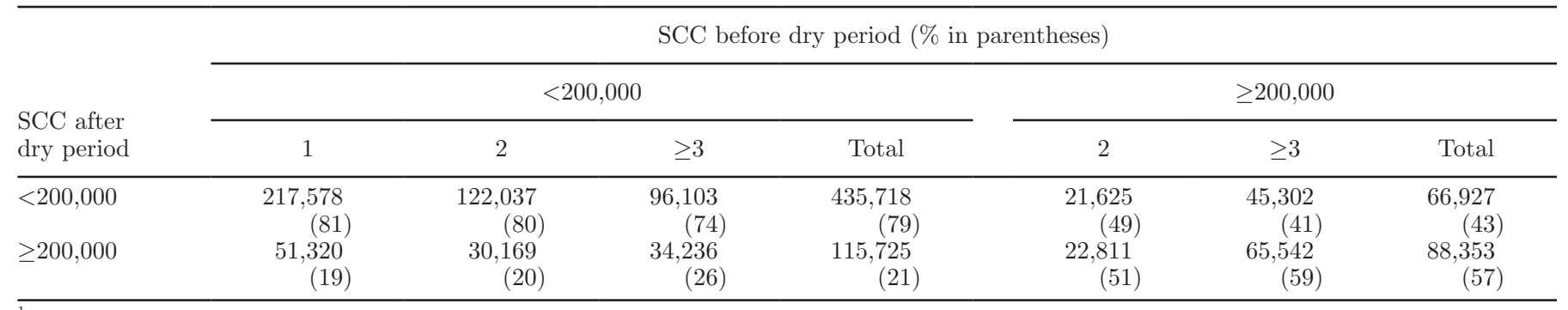

${ }^{1}$ Parity 1 was by default set to an initial value of SCC $<200,000$.

presented is that estimates of association between occurrence of elevated SCC and milking system type may vary over time. We also show that milking system type may have a different influence on prevalence compared with incidence.

We observed an identical seasonal pattern of elevated udder SCC for all $4 \mathrm{yr}, 2008$ to 2011, with a peak in August (i.e., the later part of pasture). A peak of bulk milk SCC in August to September has previously been shown, as well as a peak in heifer mastitis in late summer (Myllys and Rautala, 1995; Olde Riekerink et al., 2007). Also, the spectrum of udder pathogens varies according to season (Olde Riekerink et al., 2007; Ericsson Unnerstad et al., 2009). In Sweden there is a pasture season of at least 2 to 4 mo between May and September; however, according to common belief pasture alone cannot explain this seasonal pattern. Another hypothesis is that the seasonal pattern could be due to heat stress (Smith et al., 2013; Lambertz et al., 2014).

The occurrence of clinical mastitis as well as elevated SCC increases with parity (Olde Riekerink et al., 2007; Persson Waller et al., 2009; Verbeke et al., 2014). Higher parity was correlated with an increased risk for becoming a case (new case incidence) and a higher number of recordings with elevated SCC (case prevalence), but we saw no age effect on relapse (new case count). It is known that age is related to a higher SCC and in the assessment of SCC measurements of milk from individual cows (Brolund, 1985). The fact that age and relapse (new case count) were not correlated in the models could be due to the presence of so-called healthy survivors (i.e., the relapse cows are not kept in the herd and the older cows that remain are less prone to suffer from mastitis). However, older cows more often had elevated SCC, and a lower proportion of the older cows seemed to recover during the dry period compared with the proportion of the younger cows and hence fewer at-risk periods to become a case. In addition, the probability of becoming a new case of elevated SCC at the first test milking after calving increased by parity.
The proportion of cases of elevated udder SCC was highest in the first lactation month, and this was most prominent for first lactation cows. In addition, $19 \%$ of the primiparous cows had elevated SCC at their very first milk testing after calving. This is in accordance with the results from a study by Santman-Berends et al. (2012) where $26 \%$ of the primiparous cows had a SCC $>150,000$ cells $/ \mathrm{mL}$. Primiparous cows are especially vulnerable during early lactation and most cases of clinical mastitis in primiparous cows occur within 1 or 2 wk after calving (Olde Riekerink et al., 2007; Persson Waller et al., 2009). A high SCC in heifers in early lactation has also been shown to have a prolonged effect on udder health (Santman-Berends et al., 2012). We saw a significant breed effect in all models where SH appeared to be a risk factor compared with SRB. It has previously been shown that herds where most the cows are SRB have a better udder health compared with herds with the SH breed (Hallén Sandgren et al., 2008; Nyman et al., 2009; Persson Waller et al., 2009). It should be noted, however, that this is not necessary solely an effect of breed, but could also be that the farmer's choice of breed is associated with farmer type and certain differences in management. For example, farmers' attitude toward treatment of a case of mastitis has been shown to differ for different breeds (Nyman et al., 2007).

The association between milking system type and udder SCC in individual cows varied over time and also between the outcomes being measured. For new case incidence as well as case prevalence, AMS was a protective factor in 2009 but a potential risk factor in 2011. Regarding new case count, AMS was a risk factor for all 3 yr under study, but the effect decreased over time. The 3 outcomes reflect different aspects of SCC: to become a new case (new case incidence), relapse (new case count), and the proportion of months that a cow had elevated SCC (case prevalence). To become a case and to recover are biologically divergent, and the risk factors can thereby be diverse. The results indicate that recovery rates are lower in an AMS herd compared with 
FRÖSSLING ET AL.

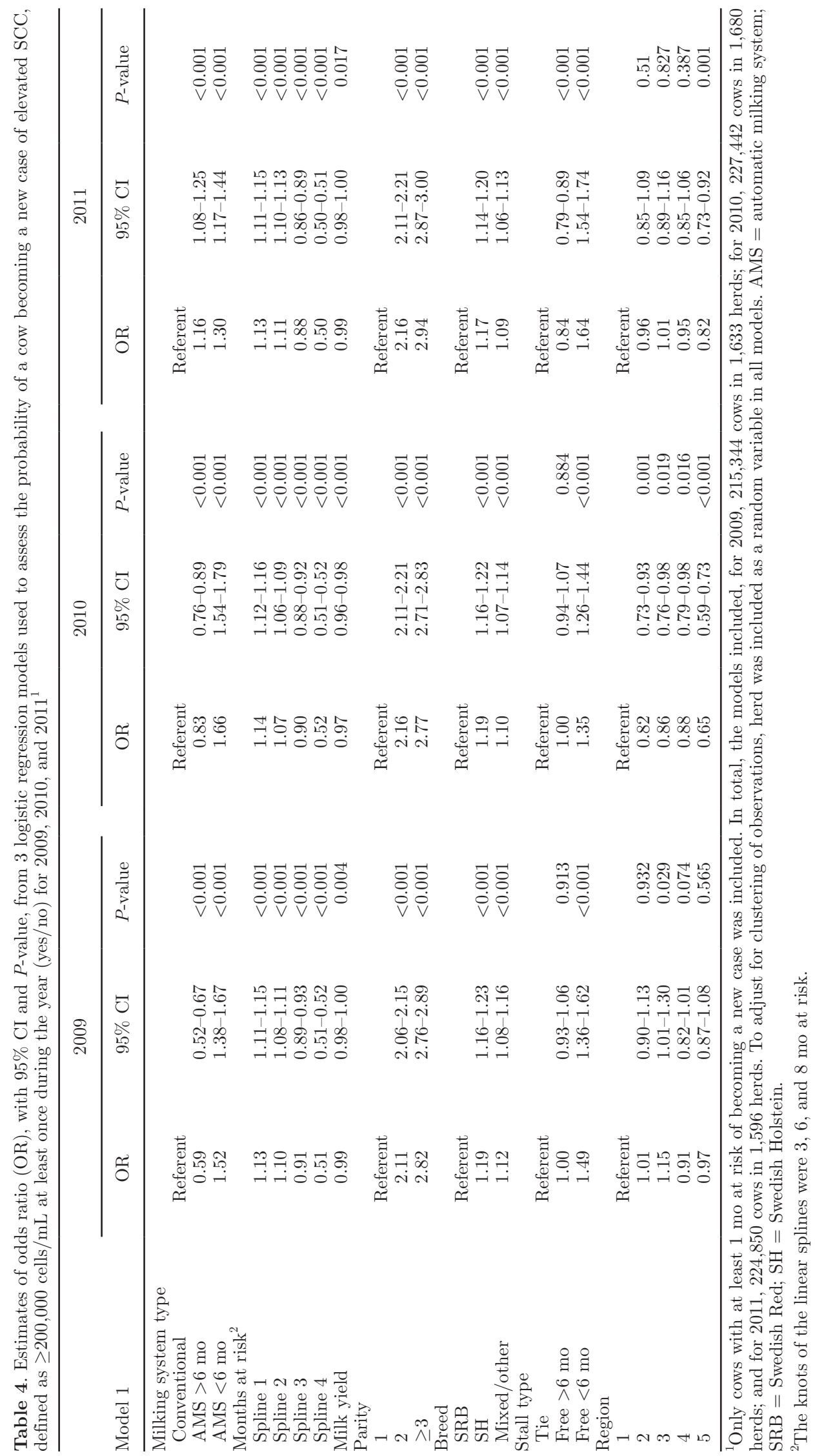


OCCURRENCE OF INCREASED SOMATIC CELL COUNT

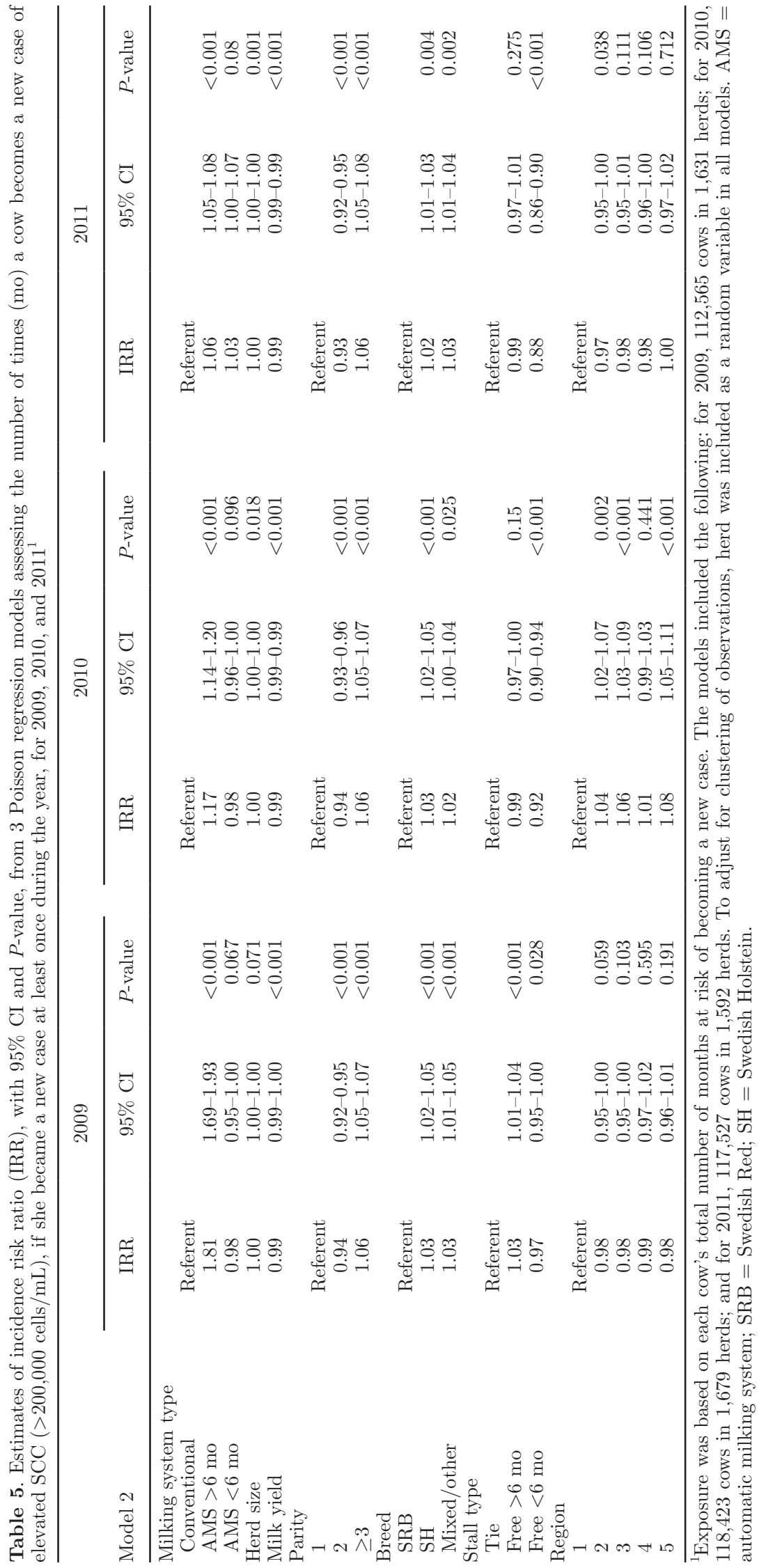


FRÖSSLING ET AL.

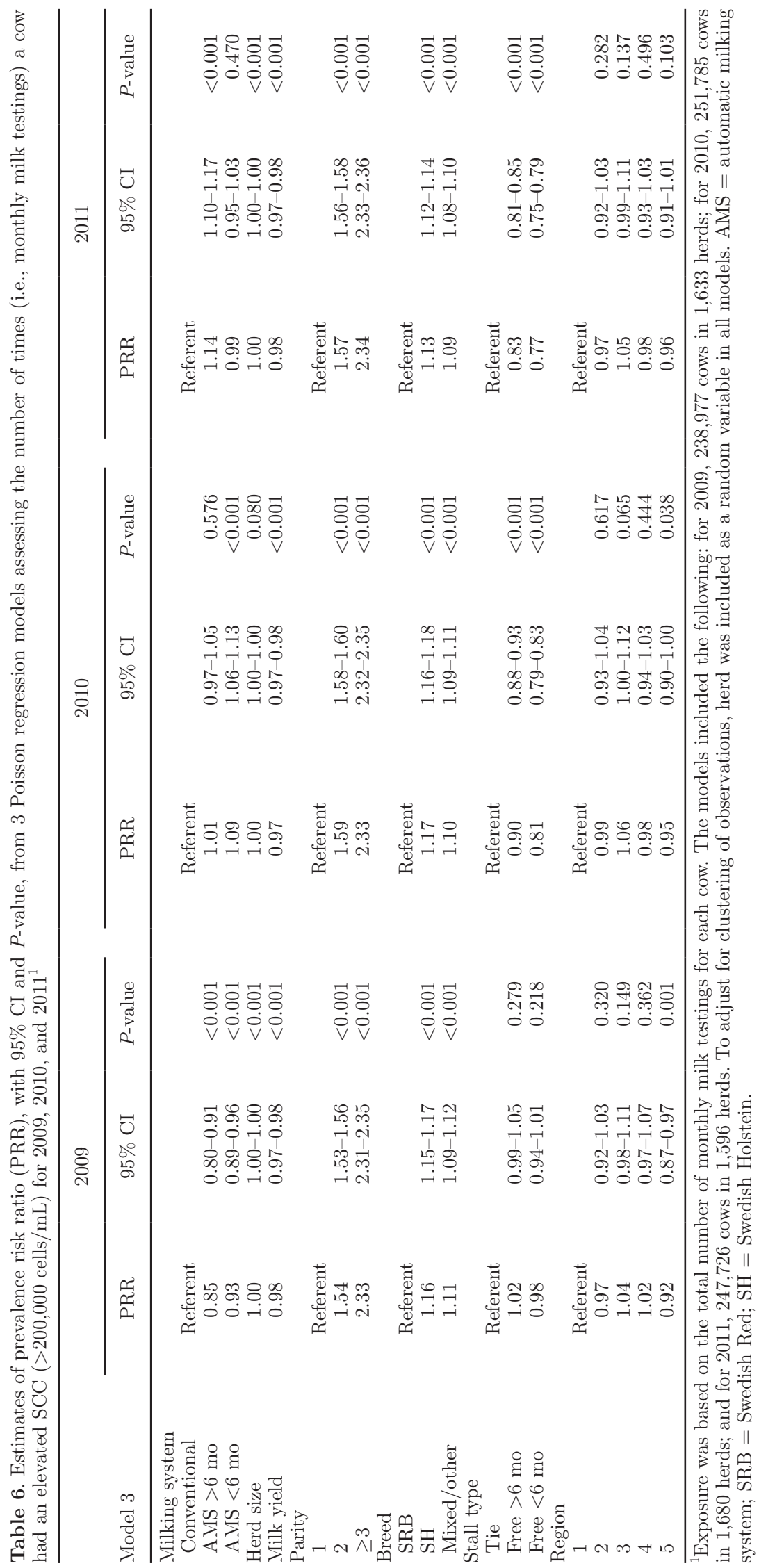


a conventional milking herd. One explanation might be that timely detection of subclinical and clinical mastitis might be more of a challenge of AMS (Hovinen and Pyörälä, 2011) and failures in detection of mastitis might increase the risk for developing chronic mastitis.

The shift for AMS from protective to potential risk factor regarding new case incidence and case prevalence might reflect a change of the AMS population over these years. In our data, the structural changes in the dairy section are clearly apparent; in 2009 there were $1.5 \%$ established AMS herds, whereas in 2011 the proportion was $31.5 \%$. One may speculate that the frontline farmers were the first ones to make the transition to AMS, and if so, this would explain why AMS was a seemingly protective factor regarding elevated SCC for herds in early transition. However, management and ambition are factors that are difficult to measure. Over the years, different brands of AMS have also been introduced on the market, and their functional differences may also be part of the explanation why the effects of AMS differ. The transition from traditional milking system to AMS was expected to have an effect on SCC. Based on our results, this was a prominent risk factor associated with new case incidence, but for the new case count and for case prevalence, no significant effect or only a small effect was shown.

Several covariates that could be expected to influence the prevalence or incidence of subclinical mastitis in cows (i.e., the units of interest) were included in our statistical analyses. The study was observational, not experimental, and therefore some variables, such as milking system type, were the same for all cows within a herd. In our models, these were included to model associations with occurrence on cow level and the hierarchical structure of the data was taken into account by using a multilevel regression model with cows clustered within herds.

To enable comparison of estimated effects, and to simplify the interpretations of estimates, only main effects were included in the final models. However, interaction between some variables was significant in some models, although not consistently over years. More detailed studies focusing on just one outcome, and more limited in time, are needed to map the causal relationship between potential risk factors for elevated SCC. Different variable effects for different years were, on the other hand, included in this study. It was confirmed that the apparent effect of fixed factors such as breed, milk yield, and parity did not change over time, whereas the effect of milking system type differed. This could be due to development of the systems per se, changes in advisory support, or differences in farmer skills and ambition. This type of information was not available to us, and the absence of potentially relevant explanatory variables in the models illustrates one disadvantage of observational studies based on analysis of information from already existing databases. Also, the study design does not allow firm conclusions about causal effects. However, apart from being less expensive to perform, studies like this may identify associations that would not be apparent in smaller scale studies.

\section{CONCLUSIONS}

An important finding was that the effect of milking system type on udder SCC varied over the years, which needs to be further investigated. The results also showed a peak in elevated SCC during the late summer season, and that the highest proportion of cases occurs during the first lactation month; the latter was most prominent for primiparous cows. These issues have previously been indicated and were here confirmed and quantified. The findings highlight the importance of appropriate management and suggest that a change in milking system does not necessarily cause problems with higher SCC in the herd.

\section{ACKNOWLEDGMENTS}

The study was financially supported by Skaraborgs läns Nötkreatursförsäkringsbolags stiftelse (Skara, Sweden).

\section{REFERENCES}

Bach, A. M., M. Dinarés, and X. Devant. 2007. Associations between lameness and production, feeding and milking attendance of Holstein cows milked with an automatic milking system. J. Dairy Res. 74:40-46.

Brolund, L. 1985. Cell counts in bovine milk. Causes of variation and applicability for diagnosis of subclinical mastitis. Acta Vet. Scand. Suppl. 80:1-123.

Dohmen, W., F. Neijenhuis, and H. Hogeveen. 2010. Relationship between udder health and hygiene on farms with an automatic milking system. J. Dairy Sci. 93:4019-4033.

Dohoo, I. R., and K. E. Leslie. 1991. Evaluation of changes in somatic cell counts as indicators of new intramammary infections. Prev. Vet. Med. 10:225-237.

Ericsson Unnerstad, H., A. Lindberg, K. Persson Waller, T. Ekman, K. Artursson, M. Nilsson-Ost, and B. Bengtsson. 2009. Microbial aetiology of acute clinical mastitis and agent-specific risk factors. Vet. Microbiol. 137:90-97.

Hallén Sandgren, C., K. Persson Waller, and U. Emanuelson. 2008. Therapeutic effects of systemic or intramammary treatment of bovine subclinical mastitis during lactation. Vet. J. 175:108-117.

Hovinen, M., and S. Pyörälä. 2011. Invited review: Udder health of dairy cows in automatic milking. J. Dairy Sci. 94:547-562.

Hovinen, M., M. D. Rasmussen, and S. Pyörälä. 2009. Udder health of cows changing from tie stalls or free stalls with conventional milking to free stalls with either conventional or automatic milking. J. Dairy Sci. 92:3696-3703

Lambertz, C., C. Sanker, and M. Gauly. 2014. Climatic effects on milk production traits and somatic cell score in lactating Holstein-Friesian cows in different housing systems. J. Dairy Sci. 97:319-329. 
Myllys, V., and H. Rautala. 1995. Characterization of clinical mastitis in primiparous heifers. J. Dairy Sci. 78:538-545.

National Veterinary Institute. 2012. SVARM 2011, Swedish Veterinary Antimicrobial Resistance Monitoring. National Veterinary Institute (SVA), Uppsala, Sweden, 2012. www.sva.se.

Nyman, A. K., T. Ekman, U. Emanuelson, A. H. Gustafsson, K. Holtenius, K. P. Waller, and C. H. Sandgren. 2007. Risk factors associated with the incidence of veterinary-treated clinical mastitis in Swedish Dairy herds with a high milk yield and a low prevalence of subclinical mastitis. Prev. Vet. Med. 78:142-160.

Nyman, A. K., U. Emanuelson, A. H. Gustafsson, and K. Persson Waller. 2009. Management practices associated with udder health of first-parity cows in early lactation. Prev. Vet. Med. 88:138-149.

Nyman, A. K., K. Persson Waller, T. W. Bennedsgaard, T. Larsen, and U. Emanuelson. 2014. Associations of udder-health indicators with cow factors and with intramammary infection in dairy cows. J. Dairy Sci. 97:5459-5473.

Olde Riekerink, R. G.. H. W. Barkema, and H. Stryhn. 2007. The effect of season on somatic cell count and the incidence of clinical mastitis. J. Dairy Sci. 90:1704-1715.

Olsson, S. O., P. Baekbo, S. O. Hansson, H. Rautala, and O. Österås 2001. Disease recording systems and herd health schemes for production diseases. Acta Vet. Scand. Suppl. 94:51-60.

Persson, Y., A. K. Nyman, and U. Grönlund-Andersson. 2011. Etiology and antimicrobial susceptibility of udder pathogens from cases of subclinical mastitis in dairy cows in Sweden. Acta Vet. Scand. $53: 36$

Persson Waller, K., B. Bengtsson, A. Lindberg, A. K. Nyman, and H. Ericsson Unnerstad. 2009. Incidence of mastitis and bacterial findings at clinical mastitis in Swedish primiparous cows-Influence of breed and stage of lactation. Vet. Microbiol. 134:89-94.

Persson Waller, K., T. Westermark, T. Ekman, and K. SvennerstenSjaunja. 2003. Milk leakage-An increased risk in automatic milking systems. J. Dairy Sci. 86:3488-3497.
Rasmussen, M.D., M. Bjerring, P. Justesen, and L. Jepsen. 2002. Milk quality on Danish farms with automatic milking systems. J. Dairy Sci. 85:2869-2878.

Santman-Berends, I. M., R. G. Olde Riekerink, O. C. Sampimon, G. van Schaik, and T. J. Lam. 2012. Incidence of subclinical mastitis in Dutch dairy heifers in the first 100 days in lactation and associated risk factors. J. Dairy Sci. 95:2476-2484.

Smith, D. L., T. Smith, B. J. Rude, and S. H. Ward. 2013. Comparison of the effects of heat stress on milk and component yields and somatic cell score in Holstein and Jersey cows. J. Dairy Sci. 96:3028-3033.

Swedish Board of Agriculture. 2010. Yearbook of Agricultural Statistics 2010. Statistics Sweden, Stockholm, Sweden. Accessed Jun. 5, 2017. https://www.jordbruksverket.se/swedishboardofagriculture/ statistics/agriculturalstatistics/2010.4.32b12c7f12940112a 7c80002141.html.

Swedish Dairy Association. 2010. Cattle statistics. Stockholm, Sweden. Accessed Jun. 5, 2017. http://www.gardochdjurhalsan.se/upload/ documents/Dokument/Startsida_Not/Kunskapsbank/Statistik/ Husdjursstatistik_Svensk_Mjolk_2010.pdf.

Växa Sverige. 2015. Redogörelse för husdjursorganisationens djurhälsovård 2013/2014. Stockholm, Sweden. Accessed Jun. 5, 2017. https://www.vxa.se/globalassets/dokument/arsredovisningo-verksamhetsberattelse/arsredovisning_husdjursnamndens_ halsoredovisning2015_16.pdf.

Verbeke, J., S. Piepers, K. Supré, and S. De Vliegher. 2014. Pathogenspecific incidence rate of clinical mastitis in Flemish dairy herds, severity, and association with herd hygiene. J. Dairy Sci. 97:69266934. 